Reviu Akuntansi dan Bisnis Indonesia, Vol. 2 No. 2, Hlm: 107-115, Desember 2018

Website: http://journal.umy.ac.id/index.php/rab

\title{
Analisis Faktor-Faktor Yang Memengaruhi Pengungkapan Islamic Social Reporting
}

\author{
Mega Arthika Dewi; Caesar Marga Putri \\ Program Studi Akuntansi Universitas Muhammadiyah Yogyakarta
}

\section{N F O A R T I K E L}

\section{Kata Kunci:}

Ukuran Dewan Komisaris,

Ukuran Perusahaan,

Profitabilitas, Likuiditas,

Daftar Efek Syariah, dan ISR.

Jenis Artikel:

Penelitian Empiris

Correspondence:

caesarmarga.putri@gmail.com

\author{
A B S T R A K
}

Tujuan dari penelitian ini adalah untuk menguji, membuktikan secara empiris dan mengetahui bahwa ukuran dewan komisaris, ukuran perusahaan, profitabilitas, dan likuiditas memiliki hubungan dengan pengungkapan ISR pada perusahaan yang termasuk dalam Daftar Efek Syariah (DES). Populasi dalam penelitian ini adalah perusahaan manufaktur yang terdaftar di Daftar Efek Syariah dan menerbitkan Laporan Tahunan secara berturut-turut tahun 2011-2017. Jumlah sampel dalam penelitian ini adalah 273. Metode pengambilan sampel dalam penelitian ini adalah purposive sampling. Teknik analisis dilakukan dengan metode regresi berganda dan juga Uji Asumsi Klasik. Hasil penelitian menunjukkan bahwa ukuran perusahaan dan profitabilitas berpengaruh positif terhadap pengungkapan Islamic Social Reporting. Sedangkan, ukuran dewan komisaris dan likuiditas tidak berpengaruh terhadap pengungkapan Islamic Social Reporting.

(C) 2019 RAB. Published by Universitas Muhammadiyah Yogyakarta

\section{PENDAHULUAN}

Salah satu tanggung jawab perusahaan adalah pertanggungjawaban sosial kepada pemangku kepentingan (stakeholders). Pelaksanaan pengungkapan dalam Corporate Social Responsibility (CSR) mempunyai peran penting untuk perusahaan dikarenakan perusahaan yang berada dalam lingkungan masyarakat dan aktivitasnya juga memliki dampak sosial dan lingkungan. Sehingga untuk menghindari konflik sosial dan lingkungan perusahaan melaksanakan pengungkapan tanggung jawab sosial yang merupakan salah satu alat manajerial yang sudah ditetapkan (Mulia, 2009). Pada dasarnya praktik CSR berorientasi dari dalam ke luar, yang artinya perusahaan harus dikelola dengan baik sehingga tidak menimbulkan dampak negatif bagi lingkungannya (Solihin, 2011). Jadi, perusahaan harus mengimplementasikan tata kelola perusahaan dengan baik dalam rangka mewujudkan CSR yang baik.

Haniffa (2002) menyatakan bahwa perkembangan CSR juga terdapat di ekonomi syariah, tidak hanya terdapat di ekonomi konvensional saja. Dalam dunia kerja ataupun penelitian, pengukuran terhadap pengungkapan CSR dalam perbankan syariah masih mengacu pada Global Reporting Initiative Index (GRI).

Saat ini peneliti-peneliti ekonomi syariah banyak menggunakan Islamic Social Reporting Index (ISR) untuk mengukur CSR institusi keuangan syariah. Menurut Haniffa (2002) ISR lebih sesuai dalam pengungkapan pelaporan CSR kaum muslim, karena tujuan awal yang mendasari adanya ISR adalah pertanggungjawaban kepada Allah SWT dan masyarakat serta meningkatkan transparansi bisnis. Dalam AAOIFI (Accounting and Auditing Organization for Islamic Financial Institutions) sudah ditetapkan komponen-komponen standar CSR untuk mengukur indeks ISR. 
Menurut Fitria dan Hartanti (2010) dalam penelitian sebelumnya menyatakan bahwa untuk mengungkapkan CSR yang sudah sesuai dengan ajaran Islam adalah dengan menggunakan indeks ISR. Pelaporan ISR saat ini masih bersifat sukarela (voluntary) karena belum terdapat standar baku dari pemerintah (Jannah dan Asrori, 2016). Adanya konsep ISR disebabkan karena saat pelaporan tanggung jawab sosial konvensional ditemukannya keterbatasan, sehingga kerangka konseptual ISR yang muncul dikatakan sesuai dengan konsep syariah. Konsep ISR tidak hanya terfokus dalam membantu proses pengambilan keputusan bagi umat muslim tetapi memilki fungsi untuk membantu perusahaan dalam rangka melaksanakan kewajiban kepada sang pencipta dan seluruh ciptaanNya (Gustani, 2015).

Beberapa penelitian tentang Islamic Social Reporting telah dilakukan sebelumnya, misalnya penelitian yang dilakukan oleh Yaya, dkk (2017), Khoirudin (2013), Sulistyawati, dkk (2017) menunjukkan hasil bahwa ukuran dewan komisaris mempunyai pengaruh positif terhadap pengungkapan Islamic Social Reporting (ISR). Penelitian yang dilakukan oleh Rosiana, dkk (2017) menunjukkan hasil bahwa ukuran perusahaan berpengaruh positif terhadap pengungkapan Islamic Social Reporting (ISR). Selanjutnya yaitu penelitian yang dilakukan oleh Yaya, dkk (2017), Widiyanti, dkk (2017), Maulida, dkk (2014) menyatakan bahwa profitabilitas mempunyai pengaruh positif terhadap pengungkapan Islamic Social Reporting (ISR). Terakhir yaitu penelitian oleh Widiyanti, dkk (2017) menunjukkan hasil bahwa likuiditas mempunyai pengaruh positif terhadap pengungkapan Islamic Social Reporting (ISR).

Dilihat dari penelitian-penelitian sebelumnya, ISR yaitu hal yang sangat penting untuk perusahaan syariah dalam rangka memenuhi harapan para pemangku kepentingan, khususnya adalah bagi masyarakat muslim. Oleh sebab itu, peneliti mencoba mengidentifikasi apa saja yang dapat memengaruhi pengungkapan Islamic Social Reporting oleh perusahaan manufaktur syariah di Indonesia di laporan tahunan periode 2011-2017. Beberapa komponen yang diyakini dapat memengaruhi perusahaan syariah dalam mengungkapkan ISR adalah ukuran dewan komisaris dan profitabilitas (Yaya dkk, 2017), ukuran perusahaan (Rosiana dkk, 2015), dan likuiditas (Widiyanti dkk, 2017).

\section{TINJAUAN LITERATUR DAN PERUMUSAN HIPOTESIS}

\section{Teori Legitimasi}

Legitimasi merupakan salah satu hal penting bagi perusahaan agar dapat mengerti mengenai batasan-batasan dalam perusahaan yang meliputi aturan-aturan dan norma serta nilai-nilai sosial mengenai reaksi yang akan mendorong organisasi untuk berperilaku sesuai nilai sosial dan aturan yang berlaku di lingkungan perusahaan (Yaya dkk, 2017). Teori legitimasi diasumsikan bahwa keberadaan suatu perusahaan bisnis dalam rangka mempertimbangkan hak-hak semua pihak dan tidak hanya terfokus pada pihak yang ada didalam perusahaan tersebut (Zubek dan Mashat, 2015). Implikasi penggunaan teori legitimasi dalam penelitian ini yaitu harapan untuk mendapatkan nilai positif serta legitimasi dari masyarakat dengan adanya pengungkapan tanggung jawab sosial perusahaan. Jika suatu perusahaan memperoleh legitimasi dari masyarakat maka perusahaan dapat bertahan dan berkembang ditengah lingkungan masyarakat, sehingga perusahaan akan memperoleh keuntungan pada masa datang (Khoirudin, 2013).

\section{Teori Stakeholder}

Dalam teori stakeholder mengungkapkan bahwa perusahaan bukanlah suatu entitas yang menjalankan bisnisnya hanya untuk kepentingan perusahaan itu sendiri akan tetapi harus dapat memberikan manfaat bagi pemegang saham, masyarakat dan pihak lainnya (Nurrokhman, 2017). Menurut Nurrokhman (2017) dalam sebuah perusahaan seorang pemangku kepentingan memiliki tugas untuk mengambil suatu keputusan di dalam islam dan diharapkan mampu menjalankan tanggung jawab sosial yang sudah sesuai dengan prinsip syariah dan membuktikan bahwa 
perusahaan tersebut menjalankan kegiatan bisnisnya sesuai dengan hukum islam. Sehingga perusahaan syariah harus menjalankan segala kegiatan sesuai syariat islam (Kariza, 2014).

\section{Syariah Enterprise Theory (Set)}

Syariah Enterprise Theory (SET) merupakan suatu teori menyatakan bahwa yang menjadi pusat dari segala sesuatu adalah Allah SWT. Manusia sebagai wakil-Nya memiliki konsekuensi wajib patuh terhadap hukum-hukum Allah SWT (Maulida dkk, 2014). Syariah Enterprise Theory dalam penelitian ini mengimplikasikan bahwa stakeholder tertinggi adalah Allah SWT sebagai pusat dan menjadi pusat untuk kembalinya manusia dan alam semesta adalah Allah SWT. Oleh sebab itu, manusia di dunia hanya sebagai khalitullah fil ardh yang mempunyai konsekuensi patuh terhadap semua hukum-hukum Allah SWT (Hafida, 2012). Hubungan pengungkapan tanggung jawab sosial berbasis syariah yang dilakukan perusahaan yaitu suatu amanah serta kewajiban sebagai mahluk Allah SWT yang tidak terlepas dari tujuan ajaran islam.

\section{Ukuran Dewan Komisaris dan Islamic Social Reporting (ISR)}

Semakin banyak dewan komisaris di dalam perusahaan, maka tingkat pengawasan dalam perusahaan akan semakin tinggi, sehingga tingkat pengawasan akan lebih baik. Dengan adanya pengawasan yang baik oleh dewan komisaris dalam perusahaan diharapkan mampu memotivasi dan mendorong tingkat pengungkapan ISR, sebagai bentuk pertanggungjawaban sosi al kepada stakeholder maupun shareholder. Penelitian Yaya, dkk (2017) dan Sulistyawati, dkk (2017) serta Khoirudin (2013) menyatakan bahwa Ukuran Dewan Komisaris berpengaruh positif terhadap pengungkapan ISR. Sehingga hipotesis pertama dirumuskan sebagai berikut :

\section{$\boldsymbol{H}_{\boldsymbol{I}}$ : Ukuran Dewan Komisaris berpengaruh positif terhadap pengungkapan ISR pada Perusahaan Manufaktur Syariah.}

\section{Ukuran Perusahaan dan Islamic Social Reporting (ISR)}

Semakin besar ukuran perusahaan maka semakin banyak pihak yang akan terlibat dengan perusahaan tersebut sehingga semakin banyak pula pihak yang akan mengawasi baik itu secara langsung maupun tidak langsung, sehingga informasi yang akan diperlukan akan semakin banyak. Pengungkapan ISR akan menjadi salah satu hal penting yang harus dilaksanakan oleh perusahaan, karena seberapa luas pengungkapan yang dilakukan akan memengaruhi persepsi stakeholder maupun shareholder kepada perusahaan. Dalam penelitian Rosiana, dkk (2015) menyatakan bahwa ukuran perusahaan berpengaruh terhadap pengungkapan ISR, namun berbeda dengan penelitian Sulistyawati, dkk (2017) dan Maulida, dkk (2014) yang menyatakan bahwa ukuran perusahaan tidak berpengaruh terhadap pengungkapan ISR. Sehingga hipotesis kedua dirumuskan sebagai berikut:

\section{$H_{2} \quad$ :Ukuran Perusahaan berpengaruh positif terhadap pengungkapan Islamic Social Reporting (ISR) pada Perusahaan Manufaktur Syariah.}

\section{Profitabilitas dan Islamic Social Reporting (ISR)}

Sebuah perusahaan yang mempunyai kemampuan menghasilkan laba yang tinggi akan menjadi perhatian bagi banyak pihak di antaranya pemerintah, hal ini terkait dengan pajak yang akan dibayarkan. Selain itu, karyawan juga akan memberikan perhatian penuh kepada perusahaan karena terkait dengan kesejahteraan mereka yang sudah bekerja disana. Dan yang terakhir yaitu masyarakat, perhatian masyarakat kepada perusahaan yang memiliki laba tinggi disebabkan karena 
masyarakat ingin mengetahui seberapa besar kontribusi perusahaan tersebut dalam mewujudkan kesejahteraan dilingkungan tersebut (Wati, 2017).

Perusahaan dengan tingkat profitabilitas tinggi akan cendrung meningkatkan pengungkapan ISRnya, sehingga harapan-harapan stakeholder dan shareholder tersebut bisa terpenuhi. Beberapa penelitian terdahulu menemukan pengaruh positif profitabilitas terhadap pengugkapan Islamic Social Reporting seperti penelitian yang dilakukan Yaya, dkk (2017), Widiyanti, dkk (2017) dan Maulida, dkk (2014). Dari pemaparan di atas maka dapat dirumuskan hipotesis ketiga yaitu:

$\mathrm{H}_{3} \quad$ : Profitabilitas berpengaruh positif terhadap pengungkapan Islamic Social Reporting (ISR) pada Perusahaan Manufaktur Syariah.

\section{Likuiditas dan Islamic Social Reporting (ISR)}

Salah satu faktor yang sering dijadikan tolok ukur investor dalam menilai kinerja perusahaan adalah dengan melihat likuiditasnya. Dalam penelitian Widiyanti, dkk (2017) menyatakan bahwa likuiditas berpengaruh positif signifikan terhadap pengungkapan ISR. Perusahaan yang memperoleh likuiditas tinggi akan mempunyai motivasi lebih besar untuk meningkatkan pengungkapan ISR, karena dengan meningkatkan pengungkapan ISR maka perusahaan akan mendapatkan kepercayaan dari pemangku kepentingan maupun perusahaan lainnya. Berbeda dengan penelitian yang dilakukan oleh Asyhari (2016) menemukan bahwa likuiditas tidak berpengaruh terhadap pengungkapan ISR. Dari penjabaran di atas maka hipotesis keempat dapat dirumuskan sebagai berikut:

\section{$\boldsymbol{H}_{4} \quad$ :Likuiditas berpengaruh positif terhadap pengungkapan Islamic Social Reporting (ISR) pada} Perusahaan Manufaktur Syariah.

\section{METODE PENELITIAN}

Dalam penelitian ini menggunakan sampel perusahaan manufaktur yang sudah terdaftar di Daftar Efek Syariah (DES) tahun 2011-2017. Dalam pengambilan sampel menggunakan teknik purposive sampling yaitu pengambilan dengan beberapa kriteria yang sudah ditetapkan, diantaranya: Perusahaan manufaktur yang menerbitkan laporan tahunan dan laporan keuangan berturut-berturut dari tahun $2011-2017$

\section{Definisi Operasional dan Pengukuran Variabel}

\section{Variable Dependen}

Variabel dependen adalah Islamic Social Reporting (ISR). ISR merupakan pengungkapan tanggungjawab sosial yang dilakukan oleh perusahaan sesuai dengan prinsip islam dan bersifat sukarela. Tingkat pengungkapan ISR akan dihitung dengan nilai (score) dari indeks Islamic Social Reporting (ISR). Indeks ISR dalam penelitian ini adalah indeks ISR yang digunakan dalam penelitian Yaya, dkk (2017) yang merupakan hasil adaptasi dari indeks ISR yang dibuat oleh Othman et al (2009).

Disclousure level $=$

Jumlah disclousure yang dipenuhi jumlah skor maksimum 


\section{Variabel Independen}

\section{a. Ukuran Dewan Komisaris}

Menurut Nurrokhmah (2017) dewan komisaris merupakan seseorang yang bertugas dalam melakukan pengawasan secara umum maupun khusus sesuai dengan anggaran dasar dan juga memberikan nasehat kepada dewan direksi. Pada penelitian ini diukur dengan cara menghitung banyaknya anggota dewan komisaris yang terdapat di perusahaan yang tercantum dalam laporan keuangan tahunan perusahaan. Pengukuran ini diambil dari penelitian sebelumnya oleh Khoirudin (2013).

Ukuran Dewan Komisaris $=\sum$ Dewan Komisaris

\section{b. Ukuran Perusahaan}

Maulida dkk, (2014) menyatakan bahwa Ukuran perusahaan adalah tingkatan besar atau kecilnya perusahaan yang bisa diukur dengan beberapa metode. Ukuran perusahaan dalam penelitian ini diukur dengan total aset perusahaan. Ukuran perusahaan yang semakin besar, maka informasi yang diberikan kepada investor dalam mengambil keputusan yang berkaitan dengan investasi yang terdapat di dalam perusahaan cenderung semakin banyak. Variabel ukuran perusahaan ini dihitung sesuai denngan penelitian sebelumnya oleh Maulida, dkk (2014) dengan menggunakan rumus berikut:

$S I Z E=\operatorname{Ln}($ Total Aset $)$

\section{c. Profitabilitas}

Profitabilitas sering digunakan oleh investor untuk menilai tingkat keberhasilan perusahaan dalam menjalankan bisnisnya, sehingga profitabilitas merupakan faktor penting yang digunakan oleh investor dalam melakukan pertimbangan sebelum mengambil keputusan untuk berinvestasi pada sebuah perusahaan (Wati, 2017). Variabel profitabilitas ini akan dihitung sesuai dengan penelitian sebelumnya oleh Yaya, dkk (2017) dengan menggunakan rumus :

$$
\mathrm{ROA}=\frac{\text { Laba Bersih Setelah Pajak }}{\text { Total Aset }}
$$

\section{d. Likuiditas}

Menurut Kamil (2012) Likuiditas dapat menunjukkan seberapa besar kemampuan suatu entitas untuk membayar utang jangka pendek pada saat jatuh tempo dengan memanfaatkan aset lancar yang sudah tersedia. Dalam penelitian ini pengukuran likuiditas akan dihitung sesuai dengan penelitian sebelumnya oleh Widiyanti, dkk (2017) menggunakan rumus:

$$
\text { Current Ratio }=\frac{\text { Current Assets }}{\text { Curent Liabilities }}
$$




\section{HASIL DAN PEMBAHASAN}

Berdasarkan metode purposive sampling diperoleh 39 perusahaan manufaktur yang memenuhi kriteria.

\section{Statistik Deskriptif}

Variabel ukuran dewan komisaris memiliki rata-rata yaitu 4,27. Nilai maksimum sebesar 12 dan nilai minimum sebesar 1 serta standar deviasinya sebesar 2,118. Ukuran perusahaan memiliki rata-rata sebesar 21 milyar, yang artinya perusahaan manufaktur di Indonesia memiliki aset yang cukup tinggi. Nilai maksimum sebesar 26 milyar, nilai minimum 12 milyar serta standar deviasi ukuran perusahaan yaitu $1,84 \%$. Profitabilitas perusahaan manufaktur di Indonesia memiliki ratarata sebesar 4,56. Nilai maksimum sebesar 26,62 dan nilai minimum sebesar -18,17 serta standar deviasinya sebesar 6,79 .

Likuiditas perusahaan manufaktur di Indonesia memiliki rata-rata sebesar 5,019. Nilai maksimumnya sebesar 464,98 dan nilai minimumnya 0,00 serta standar deviasinya sebesar 31,71. Pengungkapan ISR perusahaan manufaktur di Indonesia memiliki rata-rata sebesar 0,56 atau $56 \%$. Nilai maksimumnya sebesar 0,74 dan nilai minimumnya 0,28 serta standar deviasinya sebesar 0,098. Dilihat dari rata-rata menunjukkan pengungkapan ISR perusahaan manufaktur di Indonesia sudah cukup baik.

\section{Asumsi Klasik}

Pengujian asumsi klasik yaitu pengujian normalitas, uji multikolinearitas, uji autokorelasi dan uji heteroskedastisitas. Berdasarkan hasil uji normalitas menunjukkan nilai signifikasi sebesar 0,200 sehingga data berdistribusi normal. Hasil pengujian juga menunjukkan bahwa data tidak mengandung multikolinearitas yang ditunjukkan dengan nilai variance inflation factor (VIF) di bawah nilai 10. Begitu pula hasil pengujian tidak terdapat autokorelasi dan heteroskedastisitas. Hal ini menunjukkan bahwa data dapat digunakan untuk pengujian hipotesis (Ghozali, 2006).

\section{Hasil Penelitian}

\section{Model Regresi Berganda}

\begin{tabular}{llll}
\hline & $\mathrm{t}$ & Sig. & Keterangan \\
\hline (Constant) & 2,321 & 0,021 & \\
UDK & 1,889 & 0,060 & Ditolak \\
SIZE & 4,426 & 0,000 & Diterima \\
PROFIT & 2,958 & 0,003 & Diterima \\
LDK & 0,720 & 0,472 & Ditolak \\
\hline
\end{tabular}

Berdasarkan tabel diatas, diperoleh persamaan regresi liniear berganda sebagai berikut:

ISR $=-0,023+0,003$ UDK + 0,026 SIZE + 0,004 PROFIT - 0,007 LDK + e

Hasil pengujian pertama membuktikan ukuran dewan komisaris tidak berpengaruh terhadap pengungkapan Islamic Social Reporting. Dari hasil pengujian tersebut dapat disimpulkan bahwa besar kecilnya ukuran dewan komisaris tidak mempengaruhi kualitas pengungkapan informasi dalam perusahaan. Penyebab ukuran dewan komisaris tidak berpengaruh terhadap pengungkapan ISR kemungkinan dikarenakan dewan komisaris melaksanakan tanggung jawab lebih besar di bagian tata kelola perusahaan saja, sehingga dewan komisaris tidak dapat menjamin pelaksanaan pengawasan terhadap manajemen dalam melakukan tanggung jawab sosial dapat terlaksana secara efektif (Nurrokhmah, 2017). 
Hasil pengujian kedua membuktikan bahwa ukuran perusahaan berpengaruh positif terhadap pengungkapan Islamic Social Reporting. Hal ini menunjukkan besar kecilnya perusahaan akan mempengaruhi tingkat pengungkapan Islamic Social Reporting. Hasil dari pengujian ini membuktikan bahwa perusahaan besar akan memiliki aktivitas yang banyak sehingga melakukan kegiatan dibidang sosial yang banyak juga. Pihak luar akan memberikan tekanan lebih besar bagi perusahaan untuk melaporkan pertanggungjawaban atas kegiatan sosial yang dilakukan, hal ini dikarenakan perusahaan menjadi pusat perhatian dikalangan masyarakat. Hasil pengujian ini mendukung penelitian yang dilakukan oleh Rosiana, dkk (2015) yang menyatakan bahwa ukuran perusahaan berpengaruh terhadap pengungkapan Islamic Social Reporting.

Hasil pengujian ketiga membuktikan bahwa profitabilitas berpengaruh positif terhadap pengungkapan Islamic Social Reporting. Perusahaan yang menghasilkan profit tinggi akan menarik investor, sehingga perusahaan akan berupaya untuk memberikan informasi yang lebih baik kepada calon investor serta masyarkat dengan cara meningkatkan pengungkapan tanggung jawab sosialnya.

Hasil penelitian ini mendukung teori legitimasi yang menyatakan bahwa profitabilitas sebagai sistem nilai yang akan menjadi pencapaian perusahaan dalam meningkatkan keuntungannya sejalan dengan sistem sosial yang dilakukan oleh perusahaan dalam mengungkapkan tanggung jawab sosialnya secara islami. Serta mendukung shariah enterprise theory yang menyatakan Allah SWT sebagai pusat, bahwa profitabilitas menjadi pusat perhatian para stakeholder perusahaan dalam memotivasi untuk meningkatkan pengungkapan tanggung jawab sosial secara islami yang dilakukan perusahaan sebagai salah satu bentuk kepatuhan atas amanah yang sudah diberikan Allah SWT. Hasil penelitian ini sesuai dengan penelitian yang dilakukan oleh Maulida, dkk (2014) dan Yaya, dkk (2017) yang menyatakan bahwa profitabilitas berpengaruh positif terhadap pengungkapan Islamic Social Reporting.

Hasil pengujian keempat membuktikan bahwa likuiditas tidak berpengaruh terhadap pengungkapan Islamic Social Reporting. Hasil ini sesuai dengan penelitian Lestari (2006) yang menyatakan likuiditas tidak berpengaruh terhadap pengungkapan ISR, kemungkinan disebabkan karena perusahaan kurang memahami tingkat kualitas likuiditas didalam perusahaan, sehingga tingkat likuiditas tidak menjadi bahan untuk evaluasi perusahaan yang dianggap akan mempunyai pengaruh terhadap pengungkapan tanggung jawab sosial. Hal ini berdampak pada pada para kreditor yang tidak menilai perusahaan dari adanya pengungkapan ISR. Hasil penelitian ini sesuai dengan penelitian yang dilakukan oleh Asyhari (2016) yang menyatakan bahwa likuiditas tidak berpengaruh terhadap pengungkapan Islamic Social Reporting.

\section{KETERBATASAN PENELITIAN}

Terdapat beberapa keterbatasan yaitu penelitian ini hanya menggunakan 4 variabel saja yaitu ukuran dewan komisaris, ukuran perusahaan, profitabilitas, dan likuiditas. Sehingga hasil didalam penelitian ini belum mampu digambarkan secara umum.Dalam memberikan skor pengungkapan ISR masih subyektifitas, karena tidak terdapat standar yang baku tentang pengukuran dalam mengukur suatu indeks ISR.

\section{KESIMPULAN}

Penelitian ini bertujuan untuk menguji, membuktikan secara empiris dan mengetahui bahwa ukuran dewan komisaris, ukuran perusahaan, profitabilitas, dan likuiditas memiliki hubungan dengan pengungkapan Islamic Social Reproting. Variabel ukuran dewan komisaris tidak berpengaruh terhadap pengungkapan Islamic Social Reporting (ISR). Variabel ukuran perusahaan berpengaruh positif terhadap pengungkapan Islamic Social Reporting (ISR). Variabel profitabilitas berpengaruh positif terhadap pengungkapan Islamic Social Reporting (ISR). Variabel likuiditas tidak berpengaruh terhadap pengungkapan Islamic Social Reporting (ISR). 
Saran dalam penelitian ini yaitu ntuk mengurangi tingkat subyektifitas, maka disarankan untuk peneliti selanjutnya melibatkan orang lain dalam melakukan penilaian mengenai skor pada indeks pengungkapan ISR dan diharapkan dapat menambah variabel atau menggunakan variabel lain yang dianggap dapat mempengaruhi tingkat pengungkapan ISR seperti manajemen laba.

\section{DAFTAR PUSTAKA}

Asyhari, L. D. (2016). Pengaruh Corporate Governance Terhadap Pengungkapan ISR Bank Umum Syariah. Skripsi, Fakultas Ekonomi dan Bisnis, Universitas Muhammadiyah Yogyakarta.

Gustani. (2015). Islamic Social Reporting (ISR) Sebagai Model Pelaporan CSR Institusi Bisnis Syariah.

Hafida, A. S. (2012). Implementasi Shariah Enterprise Theory Melalui Value Added Statement untuk Menilai Tanggung Jawab Perbankan Syariah Kepada stakeholders. Skripsi, Fakultas Ekonomi dan Bisnis, Universitas Hasanuddin Semarang.

Haniffa, R. (2002). Social Reporting Disclosure: An Islamic Perspective. Indonesian Manage-ment \& Accounting Research, 1 (2), 128-146.

Kamil, A., \& Herusetya, A. (2012). Pengaruh karakteristik perusahaan terhadap luas pengungkapan kegiatan corporate social responsibility. Media Riset Akuntansi, 1 (2), 1-17.

Khoirudin, A. (2013). Corporate Governancedan Pengungkapan Islamic Social Reporting pada Perbankan Syariah di Indonesia. Accounting Analysis Journal, 2 (2), 227-232.

Kurniawati, M., \& Yaya, R. (2017). Pengaruh Mekanisme Corporate Governance, Kinerja Keuangan dan Kinerja Lingkungan terhadap Pengungkapan Islamic Social Reporting. Jurnal Akuntansi dan Investasi, 18 (2), 163-171.

Maulida, A. P., Yulianto, A., \& Asrori. (2014). Analisis Faktor-Faktor Yang Mempengaruhi Pengungkapan Islamic Social Reporting (ISR). Simposium Nasional Akuntansi, 17, 1-18.

Nazaruddin, i., \& Basuki, A. T. (2015). Analisis Dengan SPSS. Yogyakarta: Danisa Media.

Ningrum, R. A., Fachrurrozie, \& Jayanto, P. Y. (2013). Pengaruh Kinerja Keuangan, Kepemilikan Institusional Dan Ukuran Dewan Pengawas Syariah Terhadap Pengungkapan ISR. Accounting Analysis Journal, 2 (4), 1-9.

Nurrokhmah, S. A. (2017). Pengaruh Ukuran Perusahaan, Profitabilitas, Ukuran Dewan Komisaris, Surat Berharga Syariah, dan Levearge Terhadap Pengungkapan ISR. Skripsi, Fakultas Ekonomi dan Bisnis, Universitas Muhammadiyah Yogyakarta.

Othman, R., Thani, A. M., \& Ghani, E. K. (2009). Determinants of Islamic Social Reporting Among Top Shariah-Approved Companies in Bursa Malaysia. Research Journal of International Studies, (12), 4-20.

Rosiana, R., Arifin, B., \& Hamdani, M. (2015). Pengaruh Ukuran Perusahaan, Profitabilitas, Leverage, Dan Governance Score Terhadap Pengungkapan Islamic Social Reporting. Jurnal Bisnis dan Manajemen, 5 (1), 1-18.

santoso, A. L., \& Dhiyaul-Haq, Z. M. (2017). Determinan Pengungkapan Islamic Social Reporting Pada Bank Umum Syariah di Indonesia. Jurnal Dinamika Akuntansi dan Bisnis, 4 (2), 125142.

Setiawan, I., Asnawi, H. F., \& Sofyani, H. (2016). Apakah Ukuran, Profitabilitas, dan Praktik Manajemen Laba Memengaruhi Tingkat Pelaksanaan dan Pelaporan Islamic Social Reporting Pada Perbankan Syariah di Indonesia. Jurnal Dinamika Akuntansi dan Bisnis, 3 (2), 65-76.

Solihin, I. (2011). Corporate Social Responsibility From Charity to Sustainability. Jakarta: Salemba Empat.

Sulistyawati, A. I., \& Yuliani, I. (2017). Pengungkapan Islamic Social Reporting Pada Indeks Saham Syariah Indonesia. Journal Akuntansi, 13 (2), 15-27.

Wati, W. (2017). Faktor-Faktor Yang Berpengaruh Terhadap Pengungkapan Islamic Social Reporting (ISR) Pada Bank Umum Syariah di Indonesia. Skripsi, Fakultas Ekonomi dan Bisnis, Universitas Muhammadiyah Yogyakarta. 
Widiyanti, N. W., \& Hasanah, N. T. (2017). Analisis Determinan Pengungkapan Islamic Sosial Reporting. Journal Bisnis dan Manajemen Islam, 5 (2), 239-264.

Zubek, F. F., \& Mashat, A. A. (2015). Corporate Social and Environmental Responsibility Disclosure (CSRD) by Qatar Listed Companies on their Corporate Web Sites. University Bulletin, 1 (17), 109-134. 